\title{
PERSONALITY AND TURNOVER INTENTION AMONG HOTEL EMPLOYEES IN SARAWAK: ROLE OF FLOW AS MEDIATOR Mark Kasa ${ }^{1}$, Chong Jia Xin ${ }^{2}$, Sherrymina Kichin ${ }^{3 *}$, Kashif Hussain ${ }^{4}$ \\ ${ }^{1,2,3,4}$ Faculty of Hospitality \& Tourism Management, UCSI University, Malaysia. Email: "sherrymina@ucsiuniversity.edu.my
}

Article History: Received on $30^{\text {th }}$ August 2019, Revised on $30^{\text {th }}$ September 2019, Published on $14^{\text {th }}$ October 2019

\begin{abstract}
Purpose of the Study: In the hotel industry, personality brings an impact on the perception of turnover intention among employees. The lack of past studies makes this present study become important to ensure employees' performance and productivity are at highest level while reducing their turnover intention. Secondly, exhaustive review of past literature revealed that lack of studies that examined flow as mediator between personality and turnover intention in eastern phenomena, the element of positive psychology of flow necessary to be investigated. This study aims to determine whether employees' personalities have significant relationship with the turnover intention, with mediating variable of flow which was underpinned with the person-environment fit theory to investigate the outcomes.
\end{abstract}

Methodology: This study implemented a quantitative method whereby the questionnaires were given out to the hotel's employees in Sarawak. All data were analysed using SPSS software version 23.

Results: This study provides contributions to the hotel industry that are interested to identify prominent elements that influence, correlate and contribute to the possible outcomes of personality, flow and turnover intention among hotel employees in the context of eastern understanding.

Implications: The flow associated with an employee personality and turnover intention. Meanwhile, the hotel's human resource practitioners advise to always implement better working practices in recruitment or training functions to ensure the right personality to work on specific tasks are being employed and lead to lower turnover intention.

Keywords: Flow, Personality, Turnover Intention, Hotel industry, Hotel Employees, Mediator.

\section{INTRODUCTION}

To meet the needs of current competitive hotel business environment, employees in the hotel industry is expected to do job for extended hours and set their job as first precedence over their personal life (Simpson, 2000; White, 2003; Perrons, 2003). Therefore, it is obvious that the hotel industry's demand for higher working performance and high employee commitment. In this sense, the employees' behavior such as attitude (i.e. job satisfaction, organizational commitment), absenteeism, turnover intention, and productivity are typically studied in business cases in order to implant and develop program that could increase motivational level while lowering down the turnover intention among hotel employees. From these past studies, it could be concluded that ineffective programs or policies may lower flow experience and cause those who are in upper managerial and professional's positions to have higher turnover intentions (De Cieri \& Bardeol, 2009).

As for behavior influences, individual factors play important roles in this current research. The individual factors may be described as personality of an individual which can be one of the factors affecting them to act and think. Personality traits best described by utilizing the Five-Factor Model (FFM). According to McCrae and John (1992), this model comprises five (5) basic constructs namely agreeableness, neuroticism, extraversion, conscientiousness, and openness. Parasuraman and Greenhaus (2002) asserted that the five basic dimensions can help to shape the environment as it might be influenced by interaction and responsiveness of individuals and situations. Past researchers are certain that personality disposition might bring to different level of engagement, as to found out whether the highly neurotic individuals are more likely become burnout (Langelaan, Bakker, Doornen \& Schaufeli, 2006) or may experience flow orientating through personality traits, which is the aspect as a personal matter which some of the hotel employee willing to provide a priority for being engaged in their work tasks. Engagement is deemed to have the closest agreeable construct with flow experience (Bakker, 2005a; Kasa \& Hassan, 2013). This situation happens when the employees are said to be totally immersed in performing the task for their personal objectives rather than for extrinsic rewards (Bakker, 2005b) is still limited study conducted among employees with the influence of personality traits in Malaysian context.

On the contrary, past studies on personality traits from the Western context brought up to the different understanding of flow phenomena which may lead to different outcomes (Robinson, Perryman \& Hayday, 2004; Bakker \& Leiter, 2010). This is because individual biographical factors and environment to experience flow are different as compared to eastern context (Gallup, 2006). Thus, the limited literature in describing that personality disposition might bring to different level of organizational outcomes have yet to be found among the hotel employees in Malaysian context. Thus, to bridge the lacking in literature, this study proposed that (H1): personality is related to flow.

As mentioned by Csikszentmihalyi and Csikszentmihalyi (1988), flow is claimed as a positive psychology movement that has a powerful impact on fulfilling the routine life with more positive productivity as it could promote a sense of accomplishment and intense enjoyment. Furthermore, flow contributes to the sense that it will increase work productivity, innovation and employees' career development (Csikszentmihalyi, Abuhamdeh, \& Nakamura, 2005). In short, workplace's 
flow refers an absolute absorption of an activity or a state of focus (Csikszentmihalyi, 1997). The past study revealed that the employees are able to be more efficient in carrying out specific tasks, more creative and more positive in their thinking when they experience flow in their workplace (Kasa \& Hassan, 2013).

Meanwhile, turnover intention refers to as the workers' thought of exiting the present job and aims to find other jobs from different companies. According to Halpern (2005), the employees with turnover intention are likely to be less productive at work and this could be costly to the respective organization. Numerous studies in western countries found out that the work in the hotel setting was typically correlated to a variety of negative outcomes (Takahashi, Tanigawa, Tachibana, Mutou, Kage, Smith \& Iso, 2005; Akerstedt, Ingre, Broman \& Kecklund, 2008; Wirtz, Giebel, Schomann \& Nachreiner, 2008). The hotel setting, in this sense refers to night shift working hours and irregular work schedules. In saying this, the negative outcomes such as job dissatisfaction, burnout or even having the intention to quit the job tend to be experienced by those workers' who are highly committed towards their work roles (Anderson, Coffey \& Byerly, 2002). Thus, in view of challenging working environments in the hotel industry, uncertain and unstable working stations and even facing problematic customers situation may or may not influence the flow experience of the hotel employees toward turnover intention. Although the most recent study revealed that the flow is correlated with turnover intention (Kasa \& Hassan, 2016), it may not imply this present study as the time past and the result finding may be different. This is due to challenging and demanding hotel business, along with recent development of hotel software and technologies that are no longer require excessive manpower. Thus, the lacking in literature explaining flow is related to turnover intention in the hotel industry has been constructed based on previous study by Kasa and Hassan (2016) is proposed: $\left(\mathbf{H}_{\mathbf{2}}\right)$ : flow is related to turnover intention.

An exhaustive review of the literature revealed that the lacking of studies that examined flow as mediator between personality and turnover intention. Past study on flow as mediator in Malaysia reported that flow mediates the relationship between burnout and OCB among bank employees (Kasa \& Hassan, 2017). Consequently, it leads to the development to $\left(\mathbf{H}_{3}\right)$ : Flow mediates the relationship between personality and turnover intention.

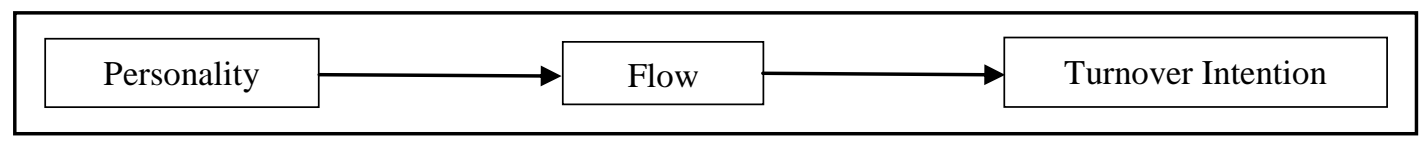

Figure 1: The Research Framework

\section{UNDERPINNING THEORY}

The theory of person-environment fit describes that the personality characteristics affect the way a person communicates with the surroundings and vice versa, (Pervin, 1989; Swartz-Kulstad \& Martin, 2000; Tinsley, 2000; Walsh, Craik \& Price, 2000). Personality characteristics consist of a person's personal needs, values, objectives, capabilities, or identity, while environmental characteristics comprise of internal and external rewards, job or roles' demand, values of culture, or attributes of other persons and cooperation in the individual's social context (French, Caplan \& Harrison, 1982). In relation to its imperative impacts in the job environment, the theory of person-environment fit has been chosen as underpinning for this present study. The focus is more on the role of the individual, whose motivations scenario may guide and direct the selection of the best working environment. This theory explains how the hotel employees' personalities will have a relationship with flow experience and turnover intention. The goal of this theory is ideal for the development of the current framework as hotel's employees with challenging working environment which exists within a challenging hotel business environment in which they feel that their task goals and searching for attainable and achievable; in this case they having low intention to quit.

\section{METHODOLOGY}

This study adopted the quantitative method approach for data collection with purposive method sampling that targets the full-time hotel employees who currently work in Sarawak hotels. The minimum sample size derived from G*Power with effect size value of $0.15,0.05$ probability error as well as 0.95 of parameter power value. Meanwhile, the G*Power generated a total of minimum sample size of 89 which this present study met the minimum sample. As recommended by Copper and Schindler (2008), this study has conducted a pilot study before the actual survey. Thus, the pilot study indeed imperative in this study as the researchers need to know about any potential errors or weaknesses in the questionnaire design or instrumentation apart from ensuring the validity and reliability of each variable. The questionnaires were also given out to the chosen hotel employees after the Human Resources Manager has approved and were gathered within onemonth period from 5 hotels in Sarawak. All of the respondent's identities and answers were secured as private and confidential. The questionnaire was designed in Bilingual languages (English and Bahasa Melayu).

\section{Research Instrument}

An exploratory factor analysis had been performed to validate all the instruments used. A total of 250 valid questionnaires were collected to confirm the validity as well as reliability aspects on the instrument used through Statistical Package for Social Science (SPSS) version 23 software. No major issue emerged with regard to the normality and outlier as each item factor loading exceeded 0.40 (Hair, 1998). The Kaiser-Meyer-Olkin (KMO) met the benchmark of 0.7, while Bartlett's 
Test of Sphericity values was below 0.5 . All the items displayed significantly varying correlation matrix in comparison to the matrix identity (Hair, 1998). All the instruments demonstrated exceptionally good results in validity and reliability scores (Nunnally, 1978), as tabulated in Table 1.

Table1: Validity and Reliability Scores

\begin{tabular}{lllllll}
\hline Measure & \multirow{2}{*}{ Items } & Sources & $\begin{array}{l}\text { Factor } \\
\text { Loading }\end{array}$ & \multirow{2}{*}{ KMO } & $\begin{array}{l}\text { Bartlett Test } \\
\text { Sphericity }\end{array}$ & $\begin{array}{l}\text { of Cronbach } \\
\text { Alpha }\end{array}$ \\
\hline Personality & 25 & Yoo \& Gretzel (2011) & .405 to .816 & .841 & $649.335, \mathrm{p}=0.000$ & 0.86 \\
\hline Flow & 13 & Bakker and Demerouti (2008) & .568 to .838 & .887 & $1792.092, \mathrm{p}=0.000$ & 0.89 \\
\hline $\begin{array}{l}\text { Turnover } \\
\text { Intention }\end{array}$ & 04 & $\underline{\text { Kelloway, Gottlieb, and Barham (1999) }}$ & .568 to .838 & .887 & $438.878, \mathrm{p}=0.000$ & 0.83 \\
\hline
\end{tabular}

\section{RESULTS AND FINDINGS}

\section{Demographic Findings}

From the total of 250 respondents consists of 141 females and 109 males. The majority of the respondents, which are 127 persons (50.8\%) categorized under the Chinese race, followed by Malay respondents, 48 persons (19.2\%), Iban, 24 respondents $(9.6 \%)$ and others race of respondents were 51 persons. For the age-wise, majority of them fall under the age group of 21 to 30 years old (36.4\%). In terms of educational level, the largest group of respondents holds a certificate under Diploma /STPM/HSC (33.2\%). The majority of the respondents are single (65.2\%) and followed by $34.8 \%$ respondents being married. Due to majority of respondents are still single, so the total of dependents for respondents mostly group under 1 to 2 members (38\%).

\section{Hypotheses Testing}

Hypothesis 1 suggested the relationship between personality and flow. Pearson Correlation Coefficient was implemented to test the correlation between personality and flow which shows the result that these two variables are significantly related $[\mathrm{r}=0.533, \mathrm{n}=250, \mathrm{p}=.000]$.

Hypothesis 2 proposed that the relationship between flow and turnover intention. A Pearson Correlation Coefficient was computed for this hypothesis, then revealed that flow is related turnover intention $[r=0.582, n=250, p=.000]$.

Hypothesis 3 determined that flow mediates between the relationship of personality and turnover intention. The Preacher and Hayes (2004)'s approach was computed through the SPSS macros for this research, which showed that the result of indirect effect of flow as mediator has stronger effect on personality and turnover rather than its main effect. According to the study's result, the indirect effect held the effect value of 0.3461 [LLCI 0.2562 , ULCI 0.4576] with the indirect effect value should be above zero or positive value ( $>0 /+$ value) and the bootstrap upper and lower bound value must above zero or positive value to determine the significant indirect correlation between the variables (Preacher \& Hayes, 2004). Therefore, it can be concluded H3 was supported.

\section{DISCUSSION}

This research supported the relationship between personality and flow. This aligned with previous researches done by Bakker (2005a; 2005b) as well as Kasa and Hassan (2013) who asserted that both personality and flow offer comparative ascribes to one another. This is because engagement is conceded to have the nearest agreeable construct with flow experience. Numerous studies revealed that personality has the capability to predict the engagement level (Macey \& Schneider, 2008; Voydanoff, 2005; Robinson et al., 2004). Furthermore, engagement is been reported significantly related to attitudes of an individual and their personality traits, which otherwise called traits engagement. In this manner, Macey and Schneider (2008) trusted that having a 'constructive effect' can be connected by engagement in which it prompts an autotelic and proactive identity, for example, performing exercises or employment errands drove by their own advantages rather than remunerations or being ethical. There is one aspect of an employee who prone to give them a predilection for being engaged, which is personality trait orientated by engagement. These personality traits have the probability of making a worker experience the ill effects of encountering flow.

The second hypothesis discovered that flow has a significant positive association with turnover intention. Hence, the study able to deduce the flow experience which poses a vital function in illustrating a significant relationship to turnover intention among the hotel employees in Sarawak. Not only that, this study found out that the existence of positive flow could bring an impact on turnover intention among the hotel employees in Sarawak. According to previous studies, experiencing flow in the work environment could signify that the hotel employees are having a positive and satisfying jobrelated mental condition characterized by vitality, commitment, and absorption (Schaufeli, Bakker \& Rhenen, 2009; Bakker, Schaufeli, Leiter \& Taris, 2008). Under this circumstance, the hotel employees would experience a more motivated workforce thereby reducing the turnover intention among them (Kasa \& Hassan, 2016). Nevertheless, this present study also revealed that the flow experience among the employees still exists even though in a challenging, complex, and complicated working environments, i.e. the hotel. 
The current study found out that the third research hypothesis is supported, in which it argued that the flow mediates between the relationship of personality and turnover. It has been shown in the past research that personality is recognized to be related to turnover intention (Robinson et al., 2004). In addition, the impacts of personality towards a change in hotel employees' attitude and behaviors are also discussed in this study, in which it caused them to vary in decision making as well as their thought to quit or continue working in the company. Besides, the flow experience among hotel employees at the workplace can differ between each person from time to time, which is prone to change on a day-to-day basis within a person's personality characteristic (Kahn, 1990; Sonnentag, 2003). Robinson et al. (2004) further revealed that the personality impacts on engagement can be varying depending on the person's gender, age, and marital status. The result indicated that women (the majority were female; $\mathrm{n}=141,56 \%$ ) show a high mean score (mean range between $4.10-6.00$ ) of flow $(n=126,50.4 \%)$ as compared to men. Meanwhile, majority are single $(n=163,65 \%)$ as they not experiencing high demand in family life as compared to married employees therefore, the single marital status employees are able to experience flow while majority of respondents are below the age of $30(n=160,64 \%)$ under the generation Y category. Generation $\mathrm{Y}$ is currently in the working life and this category of generation is expected to experience high level of motivational tendency as well because they possess high level of education level and knowledge in a specified field (White, 2003) before they are being employed in the industry.

Table2: Direct, Indirect, and Total Effect

\begin{tabular}{llllll}
\hline Variables & Direct & Indirect & Total & Lower Limit (LLCI) & Upper Limit (ULCI) \\
\hline Job Demands & -.0446 & .0366 & -.0080 & -.0093 & .0914 \\
\hline Job Resources & .2753 & .1925 & .4677 & .1072 & .3039 \\
\hline TOTAL & .2307 & .2291 & .4597 & & \\
\hline
\end{tabular}

\section{LIMITATION AND FUTURE RECOMMENDATION}

Since this study only concluded through one-off data collection technique (survey questionnaire) within 14 days (2 weeks), it possesses the drawback as the researcher unable to persuade the respondents due to no direct contact with the respondents. In addition, the absence of appearance by the researcher to manage the questionnaires had led to unwilling of the respondents to answer the questionnaires. It is recommended that future study should be conducted effectively by giving approval to the researcher to be personally managing the questionnaires at the target venue.

\section{IMPLICATIONS AND CONCLUSION}

As in past research studies have stated that the personality of an employee can affect their perception and also the engagement level to the organization, together with the turnover intention (Felstead, 2002). These research results can be concluded that flow associated with employee personality and turnover intention. Meanwhile, the hotel's human resource practitioners advise to always implement better working practices in recruitment or training functions to ensure the right personality to work on specific tasks are being employed and lead to lower turnover intention. There are numerous strategies can be done such as revisit the recruitment and selection policy of the organization to include mandatory personality and flow test to each potential candidate. Thus, this will determine the drive and vibe of each personality trait of employee candidates in experiencing flow while reducing the potential intention to quit. As to retain the valuable asset of organization, human resource practitioner should ensure that the superior level such as managers should have assigned work task or job to the employees according to their expertise and capability in work, which to avoid lay back of work productivity, as well as employees work overloaded.

\section{REFERENCES}

1. Akerstedt T., Ingre, M., Broman, J.E. \& Kecklund, G. (2008). Distributed sleep in shift workers, day workers and insomniacs. Chronobiol Int, 25(2), 333-348. https://doi.org/10.1080/07420520802113922

2. Anderson, S. E., Coffey, B. S., \& Byerly, R. T. (2002). Formal Organizational Initiatives and Informal Workplace Practices: Links to Work-Family Conflict and Job-Related Outcomes. Journal of Management, 28(6), $787-810$. https://doi.org/10.1016/S0149-2063(02)00190-3

3. Bakker, A. B. (2005). Flow among music teachers and their students: The crossover of peak experiences. Journal of Vocational Behavior, 66(1), 26-44. https://doi.org/10.1016/j.jvb.2003.11.001

4. Bakker, A. D. (2005). Job resources buffer the impact of job demands on burnout. Journal of Occupational Health Psychology, 10(2), 170-180. https://doi.org/10.1037/1076-8998.10.2.170

5. Bakker, A.B. and Demerouti, E. (2008), Towards a Model of Work Engagement. Career Development International, 13, 209-223. https://doi.org/10.1108/13620430810870476

6. Bakker, A.B., \& Leiter, M. P. (2010). Work engagement: A handbook of essential theory and research (Eds.). New York, NY: Psychology Press. https://doi.org/10.4324/9780203853047

7. Bakker, A.B., Schaufeli, W.B., Leiter, M.P. \& Taris, T. W. (2008). Work engagement: An emerging concept in occupational health psychology. Work \& Stress, 22, 187-200. https://doi.org/10.1080/02678370802393649

8. Cooper, D., \& Schindler, P. (2008). Business research methods (10th ed.). New York, NY: McGraw-Hill/Irwin.

9. Costa, P.T., JR., \& McCrae, R. R. \& M. (1985). The NEO Personality Inventory Manual. Odessa, FL: Psychological Assessment Resources. https://doi.org/10.1037/t07564-000 
10. Csikszentmihalyi, M. (1997). Finding flow: The psychology of engagement with everyday life. New York, NY: Harper Corlins.

11. Csikszentmihalyi, M. \& Csikszentmihalyi, I. S. (1988). Optimal experience: Psychological studies of flow in consciousness. New York, NY: Cambridge University Press. https://doi.org/10.1017/CBO9780511621956

12. Csikszentmihalyi, M., Abuhamdeh, S., \& Nakamura, J. (2005). Flow. In Handbook of competence and motivation (pp. 598-608). New York, NY: Guilford Publications, Inc.

13. De Cieri, H., \& Bardoel, E. A. (2009). What does "work-life management" mean in China and Southeast Asia for MNCs? Community, Work and Family, 12(2), 179-196. https://doi.org/10.1080/13668800902778959

14. Felstead, A. J. (2002). Opportunities to work at home in the context of work-life balance. Human Resource Management Journal, 12(1), 54-76. https://doi.org/10.1111/j.1748-8583.2002.tb00057.x

15. French, J. R. P., Jr., Caplan, R. D., \& Harrison, R. V. (1982). The mechanisms of job stress and strain. London: Wiley.

16. Gallup. (2006). Gallup study: engaged employees inspire company innovation: national survey finds that passionate workers are most likely to drive organizations forward. The Gallup Management Journal.

17. Hair, J. A. (1998). Multivariate data analysis (5th ed.). Upper Saddle River, NJ: Prentice Hall.

18. Halpern, D. (2005). How time-flexible work policies can reduce stress, improve health, and save money. Stress and Health, 21(3), 157-168. https://doi.org/10.1002/smi.1049

19. Kahn, W. A. (1990). Psychological Conditions of Personal Engagement and Disengagement at Work. Academy of Management Journal, 33(4), 692. https://doi.org/10.5465/256287

20. Kasa, M., \& Hassan, Z. (2013). Antecedent and Consequences of Flow: Lessons for Developing Human Resources. Procedia - Social and Behavioral Sciences, 97, 209-213. https://doi.org/10.1016/j.sbspro.2013.10.224

21. Kasa, M. \& Hassan, Z. (2016). The Role of Flow Experience among the Hotel Employees in Sarawak. Tourism Development Journal, 14(1), 98-111.

22. Kasa, M. \& Hassan, Z. (2017). Burnout Dimensions with Work-Family Conflict among Hotel Employees: Flow Experience as Mediating Role. Journal of Management \& Marketing Review, 2(2), 1-7.

23. Kelloway, E.K., Gottlieb, B.H., \& Barham, L. (1999). The source, nature, and direction of work and family conflict: A longitudinal Investigation. Journal of Occupational Health Psychology, 4, 377-346. https://doi.org/10.1037/1076-8998.4.4.337

24. Langelaan, S., Bakker, A. B., van Doornen, L. J. P., \& Schaufeli, W. B. (2006). Burnout and work engagement: Do individual differences make a difference? Personality and Individual Differences, 40(3), 521-532. https://doi.org/10.1016/j.paid.2005.07.009

25. Macey W.H. \& Schneider, B. (2008). The meaning of employee engagement. Industrial and Organizational Psychology, 1, 3-30.

26. McCrae, R. R. \& John, O. P. (1992). An introduction to the Five-Factor Model and its applications. Journal of Personality, 60(2), 175-215. https://doi.org/10.1111/j.1467-6494.1992.tb00970.x

27. Nunnally, J. C. (1978). Psychometric theory (2nd ed.). New York, NY: McGraw-Hill.

28. Parasuraman, S., \& Greenhaus, J. H. (2002). Toward reducing some critical gaps in work-family research. Human Resource Management Review, 12(3), 299-312. https://doi.org/10.1016/S1053-4822(02)00062-1

29. Perrons, D. (2003). The new economy and the work-life balance: Conceptual explorations and a case study of new media. Gender, Work and Organization, 10(1), 65-93. https://doi.org/10.1111/1468-0432.00004

30. Pervin, L. A. (1989). Goal Concepts in Personality and Social Psychology. Hillsdale: Erlbaum.

31. Preacher, K.J. \& Hayes, A. F. (2004). SPSS and SAS procedures for estimating indirect effects in simple mediation models. Behaviour Research Methods, 36(4), 717-731. https://doi.org/10.3758/BF03206553

32. Robinson, D., Perryman, S. \& Hayday, S. (2004). The drivers of employee engagement. Institute for Employment Studies, 408. Retrieved from https://www.employment-studies.co.uk/system/files/resources/files/408.pdf

33. Schaufeli, W.B., Bakker, A.B. \& Rhenen, W. V. (2009). How changes in job demands and resources predict burnout, work engagement, and sickness absenteeism. Journal of Organizational Behaviour, 30(7), 893-917. https://doi.org/10.1002/job.595

34. Simpson, R. (2000). Presenteeism and the impact of long hours on manage. In J. Winstanley, D. and Woodall (Ed.), Ethical Issue in Contemporary Human Resource Management (pp. 156-171). Macmillan: London.

35. Sonnentag, S. (2003). Recovery, work engagement, and proactive behavior: A new look at the interface between nonwork and work. Journal of Applied Psychology, 88(3), 518-528. https://doi.org/10.1037/0021-9010.88.3.518

36. Swartz-Kulstad, J.L., \& Martin, W. E. (2000). Culture as an essential aspect of person-environment fit. In W. E. M. J. \& J. L. Swartz-Kulstad (Ed.), Person-environment psychology and mental health: Assessment and intervention (pp. 169-195). Mahwah, NJ: Erlbaum.

37. Takahashi M., Tanigawa, T., Tachibana, N., Mutou, K., Kage, Y., Smith, L. \& Iso, H. (2005). Modifying effects of perceived adaption to shift work on health, wellbeing, and alertness on the job among nuclear power plant operation. Individual Health, 43(1), 171-178. https://doi.org/10.2486/indhealth.43.171

38. Tinsley, H. E. A. (2000). The congruence myth: An analysis of the efficacy of the person environment fit models. Journal of Vocational Behavior, 56(2), 147-179. https://doi.org/10.1006/jvbe.1999.1727 
39. Voydanoff, P. (2005). Toward a conceptualization of perceived work-family fit and balance: A demands and resources approach. Family, Journal of Marriage and, 67, 822-836. https://doi.org/10.1111/j.17413737.2005.00178.x

40. Walsh, W. B., Craik, K. H., \& Price, R. H. (2000). Person-environment psychology: Models and perspectives (2nd ed.). Mahwah, NJ: Erlbaum.

41. White, M. H. (2003). High-performance management practices, working hours and work-life balance. British Journal of Industrial Relations, 41, 175-195. https://doi.org/10.1111/1467-8543.00268

42. Wirtz, A., Giebel, O., Schomann, C. \& Nachreiner, F. (2008). The inteference of fhttps://doi.org/10.1080/07420520802114086

43. Yoo, K.-H., \& Gretzel, U. (2011). Influence of personality on travel-related consumer-generated media creation. Computers in Human Behavior, 27(2), 609-621. https://doi.org/10.1016/j.chb.2010.05.002 